\title{
CHRISTIAN LARROUMET: UN HOMBRE SIN FRONTERAS*
}

"La vida es una forma de exageración"

(Oscar Wilde, El retrato de Dorian Gray)

Hay personas que por la firmeza de su carácter y la pasión que imprimen a todas las actuaciones de sus vidas se imponen irremediablemente sobre todas las demás. Cuando, por azar, nos cruzamos en su camino, dejan en nosotros una marca indeleble, y sabemos que, de una u otra forma, siempre vamos a estar condicionados por la fuerza de sus ideas. Christian Larroumet es una de ellas.

Aún podemos recordar la primera de sus clases, a la que asistimos en una mañana fría de otoño. Con la ansiedad y la ilusión propias de los estudiantes latinoamericanos que llegan a París para recibir las enseñanzas de aquellos profesores cuyos nombres, a fuerza de verlos en letras de imprenta, se han tornado abstractos e incorpóreos. Nos bastó con oír la primera de sus sentencias agudas y tajantes para despertarnos del letargo y descubrir al profesor de carne y hueso, que se disponía a desafiar todos los conocimientos que habíamos recibido a lo largo de nuestros años de formación. Una a una expuso sus ideas de forma rigurosa e implacable y, en ese momento, en medio del desconcierto, supimos que él iba a determinar, en gran medida, el rumbo de nuestras vidas.

Y es que Christian Larroumet sólo ha sabido vivir de forma extrema, sin fronteras. Desde los inicios de su carrera docente se caracterizó por su sentido crítico y la originalidad de sus teorías, cualidades que, a lo largo de su vida, han despertado la admiración profunda de sus partidarios y el recelo de sus contradictores. Sin puntos intermedios.

Con esta misma pasión ha establecido todas sus relaciones personales, tanto en el seno de su familia y con sus amigos, como frente a sus estu-

* Texto publicado originalmente en Mantilla Espinosa, Fabricio y Carlos Pizarro Wilson (coords.). (2008). Estudios de derecho privado en homenaje a Christian Larroumet. BogotáSantiago: Universidad del Rosario-Universidad Diego Portales, Fundación Fueyo, pp. 11-12. Se reproduce con autorización de sus autores. 
diantes. Nuestras carreras universitarias se deben, en gran medida, a su determinación y tenacidad. Fue él, precisamente, quien, en un caso, gestionó la beca necesaria para continuar con nuestra formación académica y, en el otro, nos acogió en su despacho de abogados en París. Pero nosotros no hemos sido los únicos de sus antiguos estudiantes que han recibido su apoyo incondicional. Basta echar una mirada a los múltiples proyectos escolares que dirige en Latinoamérica y Francia para constatar que muchos de los nombres de sus integrantes coinciden con aquellos de las viejas listas de sus clases.

Resultaría completamente inútil rememorar aquí su íntima relación con Latinoamérica y, en general, con el derecho de habla hispana, cuando resulta tan fácil encontrar su nombre citado en una sentencia judicial mexicana o en un libro de doctrina chileno o, simplemente, toparse con él en las calles de Santo Domingo o Bogotá.

Este sencillo homenaje que le rendimos sus amigos y discípulos debía hacerse en la que siempre ha considerado su casa y en su idioma: en Latinoamérica y en español.

12 El pasado 23 de julio de 2021 Christian Larroumet partió definitivamente. Ya no podremos volver a verlo sentado en los cafés de Buenos Aires con su sombrero de ala ancha, ni asistir a sus demoledoras y divertidas conferencias en las aulas universitarias, ni discutir con él sobre historia al calor de una copa de burdeos. Partió, pero dejó tras de sí su obra, sin fronteras, directa, crítica, conformada por todos aquellos que nos encontramos unidos por sus enseñanzas y su recuerdo perenne.

Fabricio Mantilla Espinosa Carlos Pizarro Wilson 